\title{
Oxidorhenium(V) and Imidorhenium(V) Complexes of Pyridylpyridazine:Oxygen Atom Transfer, Oxidation and Substitution Involving Oxido, Phosphine Oxide and Phosphine Coordination
}

\author{
BIKASH KUMAR PANDA ${ }^{1}$, UMASANKAR SENAPATI ${ }^{2}$, \\ BISWARUP MONDAL ${ }^{3}$ and SUMAN SENGUPTA ${ }^{4^{*}}$
}

${ }^{1}$ Department of Chemistry, Jangipur College, Jangipur, Murshidabad-742213, W.B., India

${ }^{2}$ Department of Chemistry, Santipur College, Santipur, Nadia-741404, W.B., India

${ }^{3}$ Department of Chemistry, Sitananda College, Nandigram, Purba Medinipur-721631, India

${ }^{4}$ Department of Chemistry, Ananda Chandra College, Jalpaiguri-735101, W.B., India

sengupta.sum@gmail.com

Received 29 November 2014 / Accepted 16 December 2014

\begin{abstract}
Oxido and imido complexes of type $\operatorname{Re}^{\mathrm{V}} \mathrm{OCl}_{3}(\mathrm{dppz})$ and $\mathrm{Re}^{\mathrm{V}}(\mathrm{NPh}) \mathrm{Cl}_{3}(\mathrm{dppz})$ having meridional geometry (where dppz is 3,6-di(2-pyridyl)pyridazine) have been isolated and characterized. The oxygen atom transfer from $\mathrm{Re}^{v} \mathrm{OCl}_{3}(\mathrm{dppz})$ to $\mathrm{PPh}_{3}$ has afforded $\mathrm{Re}^{\mathrm{III}}\left(\mathrm{OPPh}_{3}\right) \mathrm{Cl}_{3}(\mathrm{dppz})$ which on chemical oxidation by $\mathrm{HNO}_{3}$ yielded $\left[\mathrm{Re}^{\mathrm{IV}}\left(\mathrm{OPPh}_{3}\right) \mathrm{Cl}_{3}(\mathrm{dppz})\right] \mathrm{ReO}_{4}$. Treatment of $\mathrm{Re}^{\mathrm{III}}\left(\mathrm{OPPh}_{3}\right) \mathrm{Cl}_{3}(\mathrm{dppz})$ with $\mathrm{PPh}_{3}$ has furnished facial $\mathrm{Re}^{\mathrm{III}}\left(\mathrm{PPh}_{3}\right) \mathrm{Cl}_{3}(\mathrm{dppz})$. The second-order rate law and large negative entropy of activation (-15.8 eu) of the oxygen atom transfer reaction of $\mathrm{Re}^{\mathrm{V}} \mathrm{OCl}_{3}(\mathrm{dppz})$ with $\mathrm{PPh}_{3}$ is consistent with an associative pathway initiating through nucleophilic phosphine attack to $\mathrm{Re} \equiv \mathrm{O} \pi^{*}$ orbitals.
\end{abstract}

Keywords: Oxidorhenium(V), Imidorhenium(V), Pyridylpyridazine, Oxygen atom transfer

\section{Introduction}

In recent years the chemistry of rhenium has moved toward new applications in the therapeutic nuclear medicine and new complexes have been developed for the selective delivery of cytotoxic radionuclides ${ }^{186} \mathrm{Re}$ and ${ }^{188} \mathrm{Re}$ to tumors ${ }^{1}$. Formation of oxido moieties constitute a dominant feature in the higher oxidation states of rhenium ${ }^{2}$. The oxygen-atom transfer ability of the oxidorhenium $(\mathrm{V})$ moiety $\mathrm{Re}^{\mathrm{V}} \mathrm{O}$ has been known for a long time and the nature and scope of the process have attracted significant recent attention ${ }^{3}$.Transfer reactions promoted by enzymatic oxido sites based on iron, molybdenum, and tungsten are 
important in the chemistry of life ${ }^{4}$. Rhenium is not a biometal in the same sense, but as an element in the periodic group next to that of molybdenum and tungsten, transfer reactions involving $\mathrm{Re}^{\mathrm{V}} \mathrm{O}$ are of value as potential models ${ }^{5}$.

The ligand 3,6-di(2-pyridyl)pyridazine (dppz, 1) is well documented to form mononuclear and cyclometallated, asymmetrically bridged dinuclear ruthenium complexes ${ }^{6}$ and also as combination of multiple metal complexes into a single heterometallic architecture $^{7}$. The copper(I) complex containing the ligand dppz can represent models for dicopper-containing proteins ${ }^{8}$. The ligand is capable of forming [2×2] grid-like metal complexes with copper(I) and silver(I) ions 9 .

To the best of our knowledge nothing is known about the oxidorhenium chemistry of dppz. Herein, we report the successful synthesis and characterization of $\operatorname{Re}^{\mathrm{v}} \mathrm{O}$ complex $\mathrm{ReOCl}_{3}(\mathrm{dppz}), 2$ incorporating chelation by 3,6-di(2-pyridyl)pyridazine, which reacts with triphenyl phosphine furnishing stable rhenium(III) phosphine oxide species $\operatorname{Re}\left(\mathrm{OPPh}_{3}\right)$ $\mathrm{Cl}_{3}(\mathrm{dppz}), 3$. The rates and activation parameters of the oxygen atom transfer are reported. The oxidorhenium $(\mathrm{V})$ complex reacts with aromatic primary amine furnishing imidorhenium(V) complex $\mathrm{Re}(\mathrm{NPh}) \mathrm{Cl}_{3}(\mathrm{dppz})$, 4. The rhenium(III) phosphine oxide complex upon metal oxidation by dilute nitric acid affords the rhenium(IV) congener $\left[\mathrm{Re}\left(\mathrm{OPPh}_{3}\right) \mathrm{Cl}_{3}(\mathrm{dppz})\right] \mathrm{ReO}_{4}, 5$. Coordinated rhenium(III) phosphine oxide are replaceable by tertiary phosphine furnishing $\mathrm{Re}\left(\mathrm{PPh}_{3}\right) \mathrm{Cl}_{3}(\mathrm{dppz}), \mathbf{6}$ but with geometrical transformation $($ meridional $\rightarrow$ facial). The spectral, electrochemical and magnetic characterization of the complexes reported in the article.<smiles>c1ccc(-c2ccc(-c3ccccn3)nn2)nc1</smiles>

dppz, 1

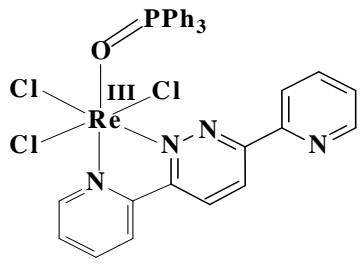

$\operatorname{Re}\left(\mathrm{OPPh}_{3}\right) \mathrm{Cl}_{3}(\mathrm{dppz}), 3$<smiles></smiles>

$\left[\operatorname{Re}\left(\mathrm{OPP} \mathrm{h}_{3}\right) \mathrm{Cl}_{3}(\mathrm{dppz})\right] \mathrm{ReO}_{4}, 5$<smiles></smiles>

$\operatorname{ReOCl}_{3}($ dppz), 2

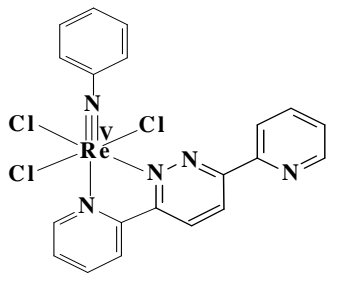

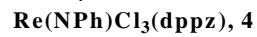<smiles></smiles>

$\operatorname{Re}\left(\mathrm{PPh}_{3}\right) \mathrm{Cl}_{3}(\mathrm{dppz}), 6$

\section{Experimental}

The concerned ligand 3,6-di(2-pyridyl)pyridazine (dppz, 1) was synthesized using available method $^{10}$. The equimolecular reaction of dppz with $\mathrm{ReOCl}_{3}\left(\mathrm{PPh}_{3}\right)_{2}$ in stirred benzene solution at room temperature afforded the orange-yellow oxido complex 2 (Eq. 1).

$$
\mathrm{ReOCl}_{3}\left(\mathrm{PPh}_{3}\right)_{2}+\mathrm{dppz} \rightarrow \mathrm{ReOCl}_{3}(\mathrm{dppz})+2 \mathrm{PPh}_{3}
$$


Use of dichloromethane as the solvent (in which 2 is soluble) in the above synthesis leads to further reaction, (Eq. 2), furnishing violet coloured complex 3 which can also be synthesized from preisolated $\mathbf{2}$ and $\mathrm{PPh}_{3}$. The oxido oxygen atom in $\mathbf{2}$ is readily substituted by the imido function upon reacting with aniline $\left(\mathrm{PhNH}_{2}\right)$ in boiling benzene to produce the blue coloured imido species 4 . The transformation which is essentially of acid-base type is stated in Eq 3.

$$
\begin{aligned}
& \mathrm{ReOCl}_{3}(\mathrm{dppz})+\mathrm{PPh}_{3} \rightarrow \operatorname{Re}\left(\mathrm{OPPh}_{3}\right) \mathrm{Cl}_{3}(\mathrm{dppz}) \\
& \mathrm{ReOCl}_{3}(\mathrm{dppz})+\mathrm{PhNH}_{2} \rightarrow \operatorname{Re}(\mathrm{NPh}) \mathrm{Cl}_{3}(\mathrm{dppz})+\mathrm{H}_{2} \mathrm{O}
\end{aligned}
$$

Electrochemical experiments (vide infra) revealed that the rhenium(IV) congener of 3 can be electrogenerated in solution. This prompted us to examine their chemical oxidation. Indeed 3 was readily oxidized by $0.1 \mathrm{~N}^{-\mathrm{HNO}_{3}}$ in acetonitrile solution furnishing 1:1 electrolytic 5 (Eq. 4) as yellow solid. It is unclear how the $\mathrm{ReO}_{4}{ }^{-}$anion originated from the starting material but this behaviour has precedence in rhenium chemistry ${ }^{5,11}$. Treatment of a solution of 3 with six fold excess of $\mathrm{PPh}_{3}$ in boiling benzene yielded green coloured 6 (Eq. 5 ). The reaction is attended with geometrical transformation ( $m e r \rightarrow f a c)$.

$$
\begin{aligned}
& 2 \mathrm{Re}\left(\mathrm{OPPh}_{3}\right) \mathrm{Cl}_{3}(\mathrm{dppz})+\mathrm{HNO}_{3} \rightarrow\left[\operatorname{Re}\left(\mathrm{PPh}_{3}\right) \mathrm{Cl}_{3}(\mathrm{dppz})\right] \mathrm{ReO}_{4} \\
& \operatorname{Re}\left(\mathrm{OPPh}_{3}\right) \mathrm{Cl}_{3}(\mathrm{dppz})+\mathrm{PPh}_{3} \rightarrow \operatorname{Re}\left(\mathrm{PPh}_{3}\right) \mathrm{Cl}_{3}(\mathrm{dppz})+\mathrm{OPPh}_{3}
\end{aligned}
$$

\section{Materials}

3,6-Di(2-pyridyl)pyridazine was synthesized by reported method ${ }^{10}$. The purification and drying of dichloromethane and acetonitrile for spectral and electrochemical work was done as before ${ }^{12}$. Benzene was distilled over sodium before use. All other chemicals and solvents were of reagent grade and were used as received.

\section{Physical measurements}

UV-Vis spectral measurements were carried out with a Shimadzu UVPC 1601 spectrometer fitted with thermostated cell compartments. IR spectra $\left(4000-100 \mathrm{~cm}^{-1}\right)$ were recorded in $\mathrm{KBr}$ disk with the help of Perkin Elmer L-0100 and Nicolet Magna IR 750 Series II spectrometers. Proton NMR spectra were recorded on a Bruker FT $300 \mathrm{MHz}$ spectrometer. In ${ }^{1} \mathrm{H}$ NMR the spin-spin structures are abbreviated as follows: $\mathrm{s}$, singlet; $\mathrm{d}$, doublet; $\mathrm{t}$, triplet: $\mathrm{m}$, multiplet and $\mathrm{b}$, broad. Electrochemical measurements were performed under nitrogen atmosphere on a $\mathrm{CH} 620 \mathrm{~A}$ electrochemical analyzer, using a platinum working electrode. The supporting electrolyte was tetraethylammonium perchlorate (TEAP), and the potentials are referred to the saturated calomel electrode (SCE) without junction correction. Microanalyses $(\mathrm{C}, \mathrm{H}, \mathrm{N})$ were performed using a Perkin-Elmer 2400 series II elemental analyzer. Solution electrical conductivity was measured in methanol $\left(\sim 10^{-3} \mathrm{M}\right.$ solution) with a Phillips PR 9500 bridge using a platinized electrode (cell constant of 1.05). Roomtemperature magnetic susceptibilities of powders were measured with a model 155 PAR vibrating sample magnetometer.

\section{Synthesis}

\section{Synthesis of $\mathrm{ReOCl}_{3}(\mathrm{dppz})$, (2)}

To a suspension of $\mathrm{ReOCl}_{3}\left(\mathrm{PPh}_{3}\right)_{2}(100 \mathrm{mg}, 0.12 \mathrm{mmol})$ in $50 \mathrm{~mL}$ benzene $28 \mathrm{mg}$ $(0.12 \mathrm{mmol})$ of dppz was added and the resulting mass was stirred at room temperature for $4 \mathrm{~h}$. The orange-yellow solid $\mathrm{ReOCl}_{3}(\mathrm{dppz})$ appeared was collected by filtration, washed thoroughly with benzene and finally dried in vacuum over fused $\mathrm{CaCl}_{2}$. Yield: $46 \mathrm{mg}(70 \%)$. Anal. Calcd. for $\mathrm{C}_{14} \mathrm{H}_{10} \mathrm{Cl}_{3} \mathrm{~N}_{4} \mathrm{ORe}$ : $\mathrm{C}, 30.91 ; \mathrm{H}, 1.86 ; \mathrm{N}, 10.31$. Found: $\mathrm{C}, 30.88 ; \mathrm{H}, 1.90 ; \mathrm{N}$, 10.34. UV-vis ( $\lambda_{\max }, \mathrm{nm}\left(\varepsilon, \mathrm{M}^{-1} \mathrm{~cm}^{-1}\right), \mathrm{CH}_{2} \mathrm{Cl}_{2}$ solution): 760(310), 470(3100), 310(12200). 
${ }^{1} \mathrm{H}$ NMR $\delta$ in $\left(\right.$ DMSO- $\left._{6}\right): 8.84(\mathrm{~d}, 1 \mathrm{H}, \mathrm{J}=6.2 \mathrm{~Hz}), 8.71(\mathrm{~d}, 1 \mathrm{H}, \mathrm{J}=7.2 \mathrm{~Hz}), 8.58(\mathrm{~d}, 1 \mathrm{H}$, $\mathrm{J}=7.6 \mathrm{~Hz}), 8.43(\mathrm{~d}, 1 \mathrm{H}, \mathrm{J}=7.1 \mathrm{~Hz}), 8.30(\mathrm{t}, 1 \mathrm{H}, \mathrm{J}=7.4 \mathrm{~Hz}), 7.96(\mathrm{~d}, 1 \mathrm{H}, \mathrm{J}=7.5 \mathrm{~Hz}), 7.76(\mathrm{t}, 2 \mathrm{H}$, $\mathrm{J}=8.6 \mathrm{~Hz}), 7.51(\mathrm{t}, 1 \mathrm{H}, \mathrm{J}=6.8 \mathrm{~Hz}), 7.36(\mathrm{~d}, 1 \mathrm{H}, \mathrm{J}=7.1 \mathrm{~Hz})$.

\section{Synthesis of $\operatorname{Re}\left(\mathrm{OPPh}_{3}\right) \mathrm{Cl}_{3}(\mathrm{dppz})$, (3)}

To $65 \mathrm{mg}(0.12 \mathrm{mmol})$ of complex 2 in dichloromethane solution $63 \mathrm{mg}$ of $(0.24 \mathrm{mmol})$ $\mathrm{PPh}_{3}$ was added and the solution was stirred magnetically at room temperature for $3 \mathrm{~h}$. During the reaction the solution colour changed from orange yellow to violet. The solution was subjected to chromatography on a silica gel column $(25 \times 1 \mathrm{~cm}, 60-120 \mathrm{mesh})$. Excess $\mathrm{PPh}_{3}$ was eluted with benzene. The violet band that followed was eluted with a benzeneacetonitrile (50:3) mixture. Solvent removal from the eluate under reduced pressure afforded $\mathrm{Re}\left(\mathrm{OPPh}_{3}\right) \mathrm{Cl}_{3}(\mathrm{dppz})$ as violet solid. Yield: $73 \mathrm{mg}(75 \%)$. Anal. Calcd. for $\mathrm{C}_{32} \mathrm{H}_{25} \mathrm{Cl}_{3} \mathrm{~N}_{4} \mathrm{OPRe}$ : C, 47.62; H, 3.13; N, 6.95. Found: C, 47.70; H, 3.15; N, 6.94. UV-vis $\left(\lambda_{\max }, \mathrm{nm}\left(\varepsilon, \mathrm{M}^{-1} \mathrm{~cm}^{-1}\right)\right.$, $\mathrm{CH}_{2} \mathrm{Cl}_{2}$ solution):730(5100), 580(3200), 470(5600). ${ }^{1} \mathrm{H}$ NMR $\delta$ in $\left(\mathrm{CDCl}_{3}\right): \mathrm{dppz}, 28.03(\mathrm{~b}$, $1 \mathrm{H}), 23.15(\mathrm{~b}, 1 \mathrm{H}), 10.20(\mathrm{~d}, 1 \mathrm{H}, \mathrm{J}=6.9 \mathrm{~Hz}), 9.78(\mathrm{~d}, 1 \mathrm{H}, \mathrm{J}=7.2 \mathrm{~Hz}), 9.28(\mathrm{t}, 1 \mathrm{H}, \mathrm{J}=7.0 \mathrm{~Hz})$, 9.08(d, 1H, J=5.8Hz), 7.29(t, 1H, J=7.4Hz), 6.89(d, 1H, J=7.1Hz), -1.31(b, 1H), -1.86(b, $1 \mathrm{H}) ; \mathrm{PPh}_{3}$ 7.53(t, 6H, J=7.3Hz), 7.09(t, 3H, J=7.6Hz), 6.69(m, 6H).

\section{Synthesis of $\operatorname{Re}(\mathrm{NPh}) \mathrm{Cl}_{3}(\mathrm{dppz})$, (4)}

To $65 \mathrm{mg}(0.12 \mathrm{mmol})$ of complex 2 in dichloromethane $56 \mathrm{mg}(0.60 \mathrm{mmol})$ aniline in $50 \mathrm{~mL}$ benzene was added and the mixture was heated to reflux for $1.5 \mathrm{~h}$, affording a blue solution. The solvent was then removed under reduced pressure, and the mass thus obtained was subjected to chromatography on a silica gel column $(20 \times 1 \mathrm{~cm}, 60-120$ mesh). Excess aniline was eluted with benzene. A blue band was then eluted with a benzene-acetonitrile $(25: 1)$ mixture. Solvent removal from the eluate under reduced pressure afforded $\operatorname{Re}(\mathrm{NPh}) \mathrm{Cl}_{3}(\mathrm{dppz})$ as a blue solid. Yield: $60 \mathrm{mg}(81 \%)$. Anal. Calcd. for $\mathrm{C}_{20} \mathrm{H}_{15} \mathrm{Cl}_{3} \mathrm{~N}_{5} \mathrm{Re}$ : C, 38.88; H, 2.45; N, 11.35. Found: $\mathrm{C}, 38.85 ; \mathrm{H}, 2.42 ; \mathrm{N}, 11.34$. UV-vis $\left(\lambda_{\max }, \mathrm{nm}\left(\varepsilon, \mathrm{M}^{-1} \mathrm{~cm}^{-1}\right), \mathrm{CH}_{2} \mathrm{Cl}_{2}\right.$ solution): $740(800), 575(2300), 320(13100) .{ }^{1} \mathrm{H}$ NMR $\delta$ in $\left(\mathrm{CDCl}_{3}\right)$ : dppz, 9.65(d, 1H, J=5.9Hz), 9.14(d, $1 \mathrm{H}, \mathrm{J}=7.5 \mathrm{~Hz}), 8.78(\mathrm{~d}, 1 \mathrm{H}, \mathrm{J}=6.1 \mathrm{~Hz}), 8.54(\mathrm{t}, 1 \mathrm{H}, \mathrm{J}=7.6 \mathrm{~Hz}), 8.31(\mathrm{t}, 1 \mathrm{H}, \mathrm{J}=6.3 \mathrm{~Hz}), 8.20(\mathrm{~d}, 1 \mathrm{H}$, $\mathrm{J}=7.0 \mathrm{~Hz}), 8.12(\mathrm{t}, 1 \mathrm{H}, \mathrm{J}=6.9 \mathrm{~Hz}), 7.96(\mathrm{t}, 1 \mathrm{H}, \mathrm{J}=6.8 \mathrm{~Hz}), 7.75(\mathrm{~d}, 1 \mathrm{H}, \mathrm{J}=5.8 \mathrm{~Hz}), 7.68(\mathrm{t}, 1 \mathrm{H}$, $\mathrm{J}=6.4 \mathrm{~Hz}) ; \mathrm{NPh}, 7.86(\mathrm{t}, 2 \mathrm{H}, \mathrm{J}=8.0 \mathrm{~Hz}), 7.38(\mathrm{t}, 1 \mathrm{H}, \mathrm{J}=6.7 \mathrm{~Hz}), 7.14(\mathrm{~d}, 2 \mathrm{H}, \mathrm{J}=8.1 \mathrm{~Hz})$.

\section{$\left[\mathrm{Re}\left(\mathrm{OPPh}_{3}\right) \mathrm{Cl}_{3}(\mathrm{dppz})\right] \mathrm{ReO}_{4},(5)$}

To $113 \mathrm{mg}(0.14 \mathrm{mmol})$ of 3 in $20 \mathrm{~mL}$ acetonitrile dilute aqueous $\mathrm{HNO}_{3}$ was added and the solution was stirred at room temperature for $0.25 \mathrm{~h}$. During this time the solution colour changed from violet to yellow. Solvent removal under reduced pressure afforded $\left[\operatorname{Re}\left(\mathrm{OPPh}_{3}\right) \mathrm{Cl}_{3}(\mathrm{dppz})\right] \mathrm{ReO}_{4}$ as an yellow solid. The solid was washed thoroughly with water to remove the adherent nitric acid and then dried in vacuum over fused $\mathrm{CaCl}_{2}$. Yield: 51 $\operatorname{mg}(69 \%)$. Anal. Calcd. for $\mathrm{C}_{32} \mathrm{H}_{22} \mathrm{Cl}_{3} \mathrm{~N}_{4} \mathrm{O}_{5} \mathrm{PRe}_{2}$ : C, 36.48; H, 2.39; N, 5.32. Found: C, 36.47; $\mathrm{H}, 2.35 ; \mathrm{N}, 5.34$. UV-vis $\left(\lambda_{\max }, \mathrm{nm}\left(\varepsilon, \mathrm{M}^{-1} \mathrm{~cm}^{-1}\right), \mathrm{CH}_{2} \mathrm{Cl}_{2}\right.$ solution): $420(900), 320(11100) .{ }^{1} \mathrm{H}$ NMR $\delta$ in $\left(\mathrm{CDCl}_{3}\right)$ : dppz, 62.81(1H), 62.26(1H), 11.44(1H), 9.92(2H), 9.03(1H), 3.84 (2H), 70.08(1H), -95.04(1H); $\mathrm{PPh}_{3}, 10.42(6 \mathrm{H}), 7.91(6 \mathrm{H}), 7.49(3 \mathrm{H}) . \Lambda_{\mathrm{M}}=102 \Omega^{-1} \mathrm{~cm}^{2} \mathrm{~mol}^{-1}$.

\section{Synthesis of $\operatorname{Re}\left(\mathrm{PPh}_{3}\right) \mathrm{Cl}_{3}(\mathrm{dppz}),(6)$}

To $73 \mathrm{mg}(0.09 \mathrm{mmol})$ of complex 3 in $30 \mathrm{~mL}$ benzene $142 \mathrm{mg}(0.54 \mathrm{mmol})$ of $\mathrm{PPh}_{3}$ was added and the mixture was heated to reflux for $2 \mathrm{~h}$. The resulting solution was evaporated to dryness and the residue was washed several times with hexane (to remove excess $\mathrm{PPh}_{3}$ ). The residue was then dissolved in $5 \mathrm{~mL}$ dichloromethane and was subjected to chromatography on a 
silica gel column. A green band was eluted with benzene-acetonitrile (25:10) mixture. Solvent removal from the eluate under reduced pressure afforded $\mathrm{Re}\left(\mathrm{PPh}_{3}\right) \mathrm{Cl}_{3}(\mathrm{dppz})$ as a green solid. Yield: $61 \mathrm{mg}(85 \%)$. Anal. Calcd. for $\mathrm{C}_{32} \mathrm{H}_{25} \mathrm{Cl}_{3} \mathrm{~N}_{4}$ PRe: C, 48.77; H, 3.20; N, 7.12. Found: $\mathrm{C}$, 48.70; H, 3.25; N, 7.04. UV-vis $\left(\lambda_{\max }, \mathrm{nm}\left(\varepsilon, \mathrm{M}^{-1} \mathrm{~cm}^{-1}\right), \mathrm{CH}_{2} \mathrm{Cl}_{2}\right.$ solution): 660(1700), $590^{\mathrm{s}}(1500), 465^{\mathrm{s}}(3000), 310(23000) .{ }^{1} \mathrm{H}$ NMR $\delta$ in $\left(\mathrm{CDCl}_{3}\right):$ dppz, 20.84(t, $\left.1 \mathrm{H}, \mathrm{J}=5.6 \mathrm{~Hz}\right)$, 20.11(t, 1H, J=6.8Hz), 19.15(d, 1H, J=6.1Hz), 16.89(d, 1H, J=6.0Hz), 6.91(d, 1H, J=6.2 Hz), $6.63(\mathrm{~d}, 1 \mathrm{H}, \mathrm{J}=7.1 \mathrm{~Hz}), 6.32(\mathrm{~d}, 1 \mathrm{H}, \mathrm{J}=6.3 \mathrm{~Hz}), 5.98(\mathrm{t}, 1 \mathrm{H}, \mathrm{J}=7.9 \mathrm{~Hz}), 1.08(\mathrm{t}, 1 \mathrm{H}, \mathrm{J}=7.1 \mathrm{~Hz}),-$ 1.98(d, 1H, J=6.4Hz); $\mathrm{PPh}_{3} 14.18(\mathrm{~d}, 6 \mathrm{H}, \mathrm{J}=6.6 \mathrm{~Hz}), 9.27(\mathrm{t}, 6 \mathrm{H}, \mathrm{J}=7.5 \mathrm{~Hz}), 8.91(\mathrm{t}, 3 \mathrm{H}, \mathrm{J}=7.3 \mathrm{~Hz})$.

\section{Rate Measurements}

A known excess of $\mathrm{PPh}_{3}$ was added to a solution of $\left[\mathrm{ReOCl}_{3}(\mathrm{dppz})\right]\left(1.25 \times 10^{-4} \mathrm{M}\right)$ in dichloromethane at the desired temperature and the thermostated reaction was followed spectrophotometrically (quartz cell, path length $1 \mathrm{~cm}$ ) by measuring the absorbance $\left(A_{t}\right)$ of the peak at $730 \mathrm{~nm}$ as a function of time, $t$. The absorbance $A_{\alpha}$ at the end of the reaction ( $\left.24 \mathrm{~h}\right)$ was also measured. Values of $k_{\text {obsd }}$ and $k$ were obtained from the slopes of the linear plots of $-\ln \left(A_{\alpha^{-}}\right.$ $\left.A_{t}\right)$ versus $t$ and $k_{\text {obs }}$ versus $\left[\mathrm{PPh}_{3}\right]$ respectively. The activation enthalpy and entropy parameters were determined from the linear plot of $-\left[\ln k h / k_{\mathrm{B}} T\right]$ versus $T^{1}$ using the Eyring equation (Eq. 6).

$$
k=\left(k_{\mathrm{B}} T / h\right)\left[\exp \left(-\Delta H^{\#} / R T\right) \exp \left(\Delta S^{\#} / R\right]\right.
$$

\section{Results and Discussion}

\section{Spectra}

In IR the oxido complex 2 displays the $\mathrm{Re}=\mathrm{O}$ stretch at $990 \mathrm{~cm}^{-1}$, two $\mathrm{Re}-\mathrm{Cl}$ stretches at 335 and $350 \mathrm{~cm}^{-1}$ and two $\mathrm{C}=\mathrm{N}$ stretches occur at 1608 and $1580 \mathrm{~cm}^{-1}$. In the imido species 4 two $\mathrm{Re}-\mathrm{Cl}$ stretches and two $\mathrm{C}=\mathrm{N}$ stretches occur at 322,341 and $1601,1585 \mathrm{~cm}^{-1}$ respectively. The rhenium(III) phosphine oxide complex 3 incorporating ReOP moiety displays a strong $\mathrm{P}=\mathrm{O}$ stretch near $1127 \mathrm{~cm}^{-1}$ while for the oxidised rhenium(IV) phosphine oxide complex 5 the $\mathrm{P}=\mathrm{O}$ stretch appear at $1118 \mathrm{~cm}^{-1}$ and a characteristic Re-O stretch of the $\mathrm{ReO}_{4}{ }_{4}^{-}$anion at $903 \mathrm{~cm}^{-1}$.

The oxido complex 2 display two absorption bands in the visible region near 760 and $470 \mathrm{~nm}$ respectively. The relatively low intensity band near $760 \mathrm{~nm}$ is consistent with substantial contribution from the ligand field transition $\mathrm{d}_{\mathrm{xy}} \rightarrow \mathrm{d}_{\mathrm{xz}}, \mathrm{d}_{\mathrm{yz}}$. The imido complex $\mathbf{4}$ also display a similar band at slightly higher energy $(740 \mathrm{~nm})$. The phosphine oxide complex 3 display two main bands in the visible region near730 and $580 \mathrm{~nm}$ associated with a number of shoulders. These are believed to be of MLCT origin. The spectra are of diagnostic value and have been employed in rate studies (vide infra). Trivalent rhenium is a potent $\pi$-donor and the metal oxidation is expected to diminish the donor power significantly ${ }^{2,5,13}$. Thus upon metal oxidation from rhenium(III) phosphine oxide 3 to rhenium(IV) phosphine oxide5 the MLCT band disappears and the lowest energy band now occurs near $420 \mathrm{~nm}$. the phosphine complex 6 shows several bands in the visible region with a prominent feature near $660 \mathrm{~nm}$. This is assigned to MLCT excitation and is believed to correspond to the band near $730 \mathrm{~nm}$ in the phosphine oxide species noted above. The blue shift in going from phosphine oxide to phosphine complex is consistent with the extra stabilization of the $t_{2 \mathrm{~g}}$ shell by the phosphine donor. The oxido and imido complexes are both diamagnetic $\left(\mathrm{d}_{\mathrm{xy}}{ }^{2}\right)$ and give rise to well resolved ${ }^{1} \mathrm{H}$ NMR lines. Chemical shifts and coupling constants for the complexes are listed in the experimental section. The phosphine oxide complex $\mathbf{3}$ and the phosphine chelate $\mathbf{6}$ have magnetic moment value of $2.08 \mu \mathrm{B}$ and $2.14 \mu \mathrm{B}$ as in several other rhenium(III) species and the ${ }^{1} \mathrm{H}$ NMR spectra is found to be paramagnetically shifted ${ }^{2,5,13,14}$. The spectra of $\operatorname{Re}(\mathrm{NPh}) \mathrm{Cl}_{3}(\mathrm{dppz}), \operatorname{Re}\left(\mathrm{OPPh}_{3}\right) \mathrm{Cl}_{3}(\mathrm{dppz})$, $\left[\mathrm{Re}\left(\mathrm{OPPh}_{3}\right) \mathrm{Cl}_{3}(\mathrm{dppz})\right] \mathrm{ReO}_{4}$ and $\mathrm{Re}\left(\mathrm{PPh}_{3}\right) \mathrm{Cl}_{3}(\mathrm{dppz})$ are shown in Figure 1. 

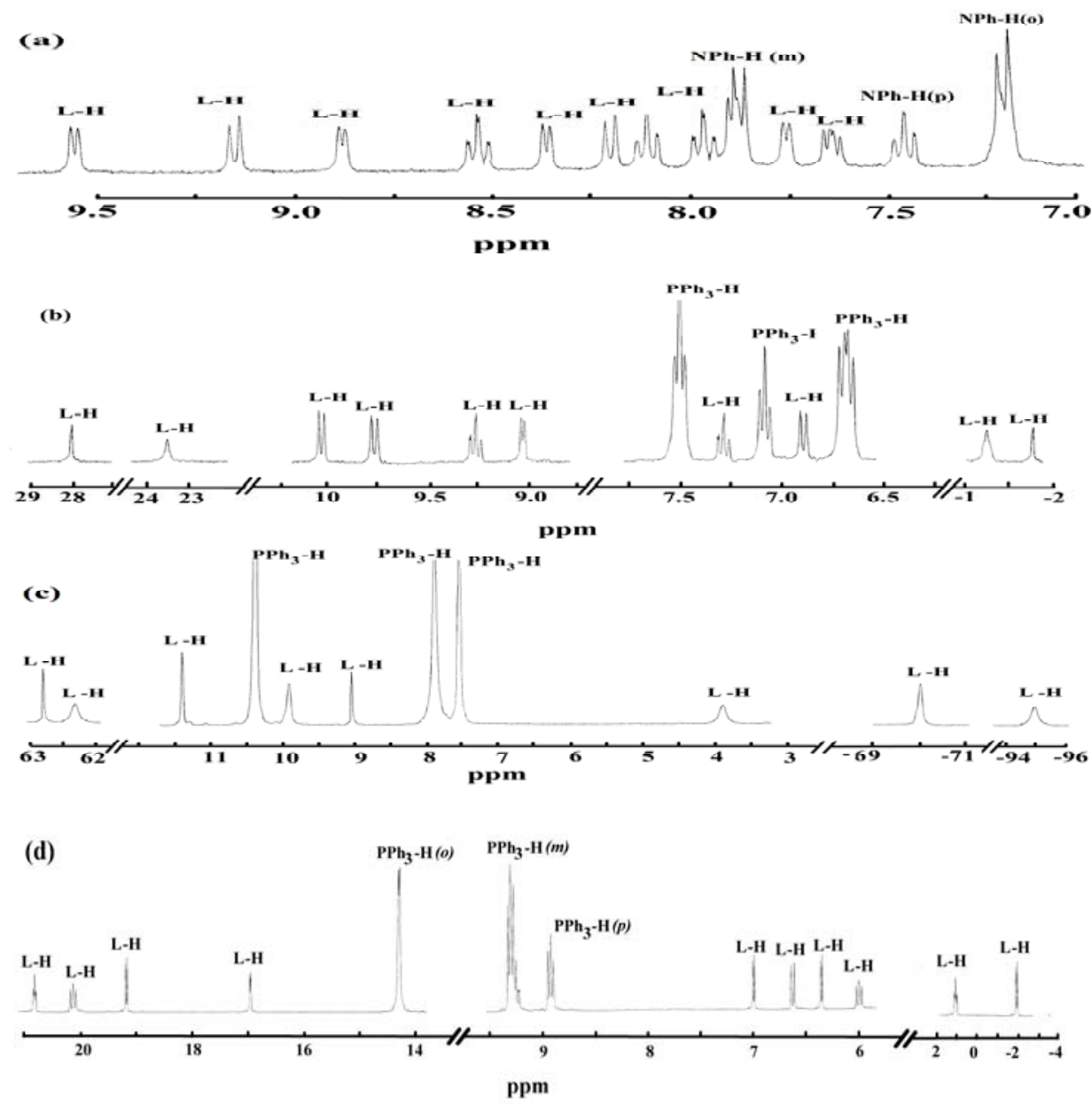

Figure 1. ${ }^{1} \mathrm{H}$ NMR spectra in $\mathrm{CDCl}_{3}$ solution of (a) $\mathrm{Re}(\mathrm{NPh}) \mathrm{Cl}_{3}(\mathrm{dppz})$ (b) $\operatorname{Re}\left(\mathrm{OPPh}_{3}\right)$ $\mathrm{Cl}_{3}(\mathrm{dppz})$ (c) $\left[\mathrm{Re}\left(\mathrm{OPPh}_{3}\right) \mathrm{Cl}_{3}(\mathrm{dppz})\right] \mathrm{ReO}_{4}(\mathrm{~d}) \mathrm{Re}\left(\mathrm{PPh}_{3}\right) \mathrm{Cl}_{3}(\mathrm{dppz})$, the L-H protons corresponds to dppz protons, $\mathrm{NPh}-\mathrm{H}$ corresponds to amine protons and $\mathrm{PPh}_{3}-\mathrm{H}$ corresponds to phosphine protons.

\section{Metal redox}

The complexes are uniformly electroactive in acetonitrile solution. The oxido and the imido species display quasireversible (peak-to-peak separation $80-100 \mathrm{mV}$ ) one-electron response corresponding to $\mathrm{Re}^{\mathrm{VI}} / \mathrm{Re}^{\mathrm{V}}$ couple having $\mathrm{E}_{1 / 2}$ of 1.58 and $0.88 \mathrm{~V}$ versus SCE respectively signifying superior stabilization of $\mathrm{Re}^{\mathrm{VI}}$ state upon imido coordination as compared to oxido coordination. Clearly defined metal reduction (say from +5 to +4 or +3 states) could not be observed electrochemically. However, chemical reduction of the oxido complex is readily achieved. Thus tertiary phosphine affords trivalent phosphine oxide complex 3 (Eq. 2) which display one-electron response near $0.30 \mathrm{~V}$ (peak to peak separation $80 \mathrm{mV}$ ) corresponding to $\mathrm{Re}^{\mathrm{IV}} / \mathrm{Re}^{\mathrm{III}}$ couple. The rhenium(IV) species $\mathbf{5}$ have the same voltammogram (opposite scan direction) as 3 . In the phosphine complex 6 the $\mathrm{Re}^{\mathrm{IV}} / \mathrm{Re}^{\mathrm{III}}$ reduction potential lie near $0.60 \mathrm{~V}$ with peak-to-peak separation of $85 \mathrm{mV}$. The increase in 
the reduction potential in the phosphine complex is consistent with the stabilization of $t_{2 \mathrm{~g}}$ shell via back-bonding to phosphorus. The voltammograms of $\operatorname{ReOCl}_{3}(\mathrm{dppz})$, $\mathrm{Re}(\mathrm{NPh}) \mathrm{Cl}_{3}(\mathrm{dppz}), \operatorname{Re}\left(\mathrm{OPPh}_{3}\right) \mathrm{Cl}_{3}(\mathrm{dppz})$ and $\mathrm{Re}\left(\mathrm{PPh}_{3}\right) \mathrm{Cl}_{3}(\mathrm{dppz})$ are shown in Figure 2.

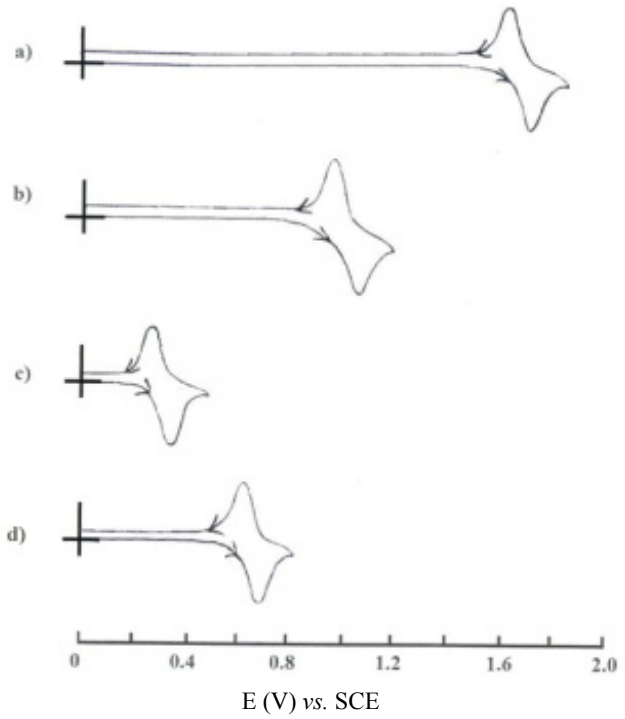

Figure 2. Cyclic voltammogram of a) $\mathrm{ReOCl}_{3}(\mathrm{dppz})$ b) $\mathrm{Re}(\mathrm{NPh}) \mathrm{Cl}_{3}(\mathrm{dppz})$ c) $\operatorname{Re}\left(\mathrm{OPPh}_{3}\right) \mathrm{Cl}_{3}$ (dppz) d) $\mathrm{Re}\left(\mathrm{PPh}_{3}\right) \mathrm{Cl}_{3}(\mathrm{dppz})$ in acetonitrile solution.

\section{Bonding and isomer preference}

Some qualitative aspects of bonding in $\mathrm{ReOCl}_{3}(\mathrm{dppz})$ will be considered assuming the idealized geometry, 7 with $\mathrm{Re} \equiv \mathrm{O}$ defining the $\mathrm{z}$-axis. The filled $\mathrm{p}_{\mathrm{z}}$ orbital of the oxido oxygen atom is used for the $\sigma$-hybridization and the filled $\mathrm{p}_{\mathrm{x}}, \mathrm{p}_{\mathrm{y}}$ orbitals are used for $\pi$-bonding with metal $\mathrm{d}_{\mathrm{xz}}, \mathrm{d}_{\mathrm{yz}}$ orbitals. The latter orbitals are destabilized and the two metal electrons $\left(\mathrm{Re}^{\mathrm{V}}, 5 \mathrm{~d}^{2}\right)$ occupy the $\mathrm{d}_{\mathrm{xy}}$ orbital in a paired configuration. A relatively weak band observed near $760 \mathrm{~nm}$ (vide infra) is tentatively assigned to $\mathrm{d}_{\mathrm{xy}} \rightarrow \mathrm{d}_{\mathrm{xz}}, \mathrm{d}_{\mathrm{yz}}$ transition.

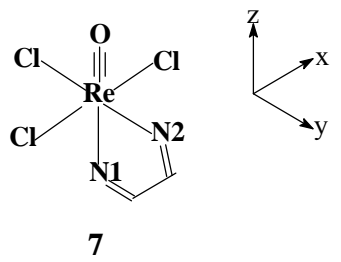

The filled $\mathrm{d}_{\mathrm{xy}}$ orbital can interact with the empty pyridazine $\pi^{*}(\mathrm{C}=\mathrm{N})$ orbital, the sense of electron donation being $\operatorname{Re} \rightarrow \pi^{*}$. A synergestic $\pi$ interaction of type $\pi^{*} \leftarrow \operatorname{Re} \leftarrow O$ is thus possible, provided the pyridazine nitrogen and the oxido oxygen atoms lie cis to each other as in the observed structure.

Steric and electronic factors alone are expected to favour meridional geometry as observed in the cases of $\mathrm{ReOCl}_{3}(\mathrm{dppz})$ and $\mathrm{Re}(\mathrm{NPh}) \mathrm{Cl}_{3}(\mathrm{dppz})$. Like the oxido and imido ligands the $\mathrm{OPPh}_{3}$ ligands are pure donors and optimum metal-ligand bonding is achievable in the meridional geometry, there being no bonding advantage for the sterically unfavourable facial disposition of ligands. It is thus logical that $\mathrm{Re}\left(\mathrm{OPPh}_{3}\right) \mathrm{Cl}_{3}(\mathrm{dppz})$ assumes 
meridional geometry like the oxido and the imido species. Upon substitution of $\mathrm{OPPh}_{3}$ by $\mathrm{PPh}_{3}$ the bonding situation changes considerably due to phosphine $\pi$-acidity, the concerned orbitals being a mixture of $3 \mathrm{~d} \pi$ and P-C $\sigma^{*}$ components $^{16}$. There are thus two good $\pi$-acceptors in the phosphine complexes: dppz and $\mathrm{PPh}_{3}$. The back-bonding effect is maximized in the facial disposition which ensures minimum competition between the two ligands for identical metal orbitals. The observed geometrical selectivity is strong and exclusive. In no case isomers have been observed for the same complex. The strong geometrical discrimination by phosphine oxide and phosphine ligands is emerging as a general phenomenon ${ }^{2,5,13,14,15}$ for $\mathrm{ReCl}_{3}(\mathrm{NN})$ complexes where $\mathrm{NN}$ is a chelated $\pi$-acidic ligand. The present dipyridylpyridazine complexes augment this class.

\section{Oxygen atom transfer}

The variable-temperature rates of the reaction of Eq. 2 have been studied spectrophotometrically in $\mathrm{CH}_{2} \mathrm{Cl}_{2}$ solution. Time evolution spectra are characterized by isosbestic point is shown in Figure 3. Under pseudo-first order condition (excess $\mathrm{PPh}_{3}$ ), the rates are proportional to the concentration of the oxido complex and the observed rate constant, $k_{\text {obsd }}$, is proportional to the concentration of $\mathrm{PPh}_{3}$. The reaction law is thus second order (Eq. 7).

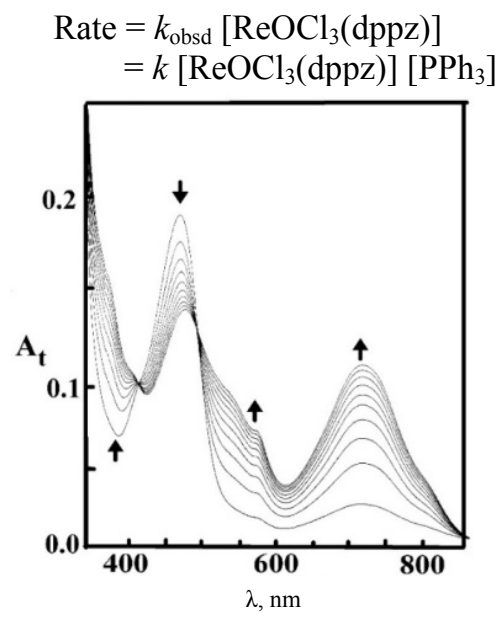

Figure 3. Time evolution spectra for the reaction of $\mathrm{ReOCl}(\mathrm{dppz})$ with $\mathrm{PPh}_{3}$ in $\mathrm{CH}_{2} \mathrm{Cl}_{2}$ solution at $302 \mathrm{~K}$

The rate constant $k$ follows the Eyring equation (Eq. 6). Rate data and the activation parameters are listed in Table 1. The negative entropy of activation of the oxygen atom transfer process as revealed in the reaction of $\left[\mathrm{ReOCl}_{3}(\mathrm{dppz})\right]$ with $\mathrm{PPh}_{3}$ is consistent with an associative transition state. A probable model for the association and progress of the reaction is stylized in $\mathbf{8}$ which is constructed in the light of previous work and the findings of oxygen atom transfer reactions involving $\mathrm{Mo}^{\mathrm{VI}} \mathrm{O}_{2}$ and $\mathrm{W}^{\mathrm{VI}} \mathrm{O}_{2}$ species ${ }^{3-5}$.

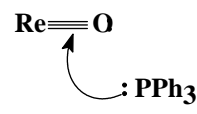

(a)<smiles></smiles>

(b)<smiles></smiles>

(c) 
In 8 the full and broken lines, respectively, represent coordinate covalent bonds and weak links. Following attack on $\pi^{*}(\mathrm{ReO})$ orbitals by the phosphine lone pair $(\mathbf{8 a})$, the $\pi$-bonds are weakened and a O---P link is established (8b, transition state). In the end, the $\mathrm{P}=\mathrm{O}$ bond remains coordinated to the metal as in $\mathbf{8 c}$.

Table 1. Rate constants for the reaction of $\left[\mathrm{ReOCl}_{3}(\mathrm{dppz})\right]+\mathrm{PPh}_{3} \rightarrow\left[\mathrm{Re}\left(\mathrm{OPPh}_{3}\right) \mathrm{Cl}_{3}(\mathrm{dppz})\right]$ in dichloromethane solution ${ }^{\mathrm{a}, \mathrm{b}}$.

\begin{tabular}{|c|c|c|c|c|}
\hline $\mathrm{T}, K$ & $10^{2}, \mathrm{PPh}_{3}$ & $10^{5} k_{\text {obsd }}, \mathrm{s}^{-1}$ & $10^{3} k, \mathrm{M}^{-1} \mathrm{~s}^{-1}$ & \multirow{4}{*}{$\begin{array}{l}\Delta \mathrm{H}^{\#}=16.06(0.1) \\
\mathrm{kcal} \mathrm{mol}^{-1}\end{array}$} \\
\hline \multirow{3}{*}{302} & 1.06 & 7.028 & \multirow{3}{*}{$6.63(0.03)$} & \\
\hline & 1.40 & 9.250 & & \\
\hline & 2.00 & 13.258 & & \\
\hline \multirow[t]{3}{*}{305} & 1.06 & 9.080 & \multirow{3}{*}{$8.72(0.02)$} & $\Delta \mathrm{S}^{\#}=-15.80(0.3) \mathrm{cal}$ \\
\hline & 1.40 & 12.027 & & $\mathrm{~K}^{-1} \mathrm{~mol}^{-1}$ \\
\hline & 2.00 & 17.273 & & \\
\hline \multirow[t]{3}{*}{308} & 1.06 & 11.601 & \multirow{3}{*}{$11.35(0.05)$} & \\
\hline & 1.40 & 15.506 & & \\
\hline & 2.00 & 22.280 & & \\
\hline
\end{tabular}

${ }^{a}$ The initial concentration of $\left[\mathrm{ReOCl}_{3}(\mathrm{dpp} z)\right]$ is $1.25 \times 10^{-4} \mathrm{M} .{ }^{b}$ Least-squares deviations are given in parentheses

\section{Conclusion}

Oxidorhenium $(\mathrm{V})$ complex of dipyridylpyridazine has been isolated in the form of $\mathrm{ReOCl}_{3}(\mathrm{dppz})$ from which the corresponding $\operatorname{Re}^{\mathrm{III}}\left(\mathrm{OPPh}_{3}\right) \mathrm{Cl}_{3}(\mathrm{dppz})$ and $\operatorname{Re}^{\mathrm{V}}(\mathrm{NPh}) \mathrm{Cl}_{3}$ (dppz) species have been prepared. The reactions are stereoretentive, the $\mathrm{ReCl}_{3}$ moiety being uniformly meridional in geometry. The phosphine oxide complex of the trivalent rhenium is chemically oxidized to rhenium(IV) congener. Displacement of coordinated phosphine oxide by phosphine is attended with meridional $\rightarrow$ facial geometrical transformation.

The oxidorhenium(V) and the imidorhenium(V) complexes are uniformly diamagnetic and a relatively weak band in the region $740-760 \mathrm{~nm}$ is believed to have considerable ligand field character. The quasireversible one-electron $\mathrm{Re}^{\mathrm{VI}} / \mathrm{Re}^{\mathrm{V}}$ reduction potential is much higher in the oxido complex $(1.58 \mathrm{~V})$ than in the imido $(0.88 \mathrm{~V})$ complex signifying superior stabilization of the hexavalent state upon imido coordination. Rhenium(III) phosphine oxide complex show two bands in the visible region near 730 and $470 \mathrm{~nm}$ while for the phosphine complex prominent feature is observed around $660 \mathrm{~nm}$. The quasireversible one-electron $\mathrm{Re}^{\mathrm{IV}} / \mathrm{Re}^{\mathrm{III}}$ reduction potential is much higher in the phosphine complex $(0.60 \mathrm{~V})$ than in the phosphine oxide $(0.30 \mathrm{~V})$ complex. The blue shift of the MLCT excitation in going from the phosphine oxide to phosphine complex and the increase in the reduction potential in the phosphine complex is consistent with the extra stabilization of the $t_{2 \mathrm{~g}}$ shell via back-bonding to phosphorus. Upon metal oxidation from rhenium(III) phosphine oxide to rhenium(IV) phosphine oxide the MLCT band disappears and the lowest energy band in the rhenium(IV) complex occurs near $420 \mathrm{~nm}$ signifying considerable reduction of $\pi$-donor power of trivalent rhenium upon metal oxidation. The rates and activation parameters of the bimolecular oxygen atom transfer process have been quantitated. The entropy of activation is negative consistent with an associative model. 


\section{References}

1. Couillens X, Gressier M, Dartiguenava M, Fortin S and Beauchamp A L, J Chem Soc., Dalton Trans., 2002, 3032-3036, DOI: 10.1039/B201632J; Bereauchamp A L, Khan S I and Abu-Omar M M, Inorg Chem., 2001, 40, 6767-6773, DOI:10.1021/ic0108033.

2. Chakravorty A, Eur J Inorg Chem., 2005, 4863-4874, DOI: 10.1002/ejic.200500615; Abram U, Comprehensive Coordination Chemistry II, Volume 5, Edited by McCleverty JA and Meyer T J, 2004, Elsevier, Oxford.

3. Sengupta S and Chakravorty A, J Indian Chem Soc., 2006, 83, 556-562; Gangopadhyay J, Sengupta S, Bhattacharyya S, Chakraborty S and Chakravorty A, Inorg Chem., 2002,41,2616-2622, DOI: 10.1021/ic011064t; Seymore S B and Brown S N, Inorg Chem., 2000, 39, 325-332, DOI: 10.1021/ic990851b; Bryan J C, Stenkamp R E, Tulip T H, Mayer J M, Inorg Chem., 1987, 26(14), 2283-2288, DOI: 10.1021/ic00261a024; Rowbottom J F and Wilkinson G, J Chem Soc., Dalton Trans., 1972, 826-830, DOI: 10.1039/DT9720000826.

4. Hille R, Chem Rev., 1996, 96(7), 2757-2816, DOI: 10.1021/cr950061t; Holm R H, Kennepohl P and Solomon E, I, Chem Rev., 1996, 96(7), 2239-2314, DOI:10.1021/cr9500390.

5. Sengupta S and Chakravorty A, J Indian Chem Soc., 2006, 83, 961-972.

6. Ghumaan S, Sarkar B, Patra S, Parimal K, Slageren J v, Fiedler J, Kaim W and Lahiri G K, Dalton Trans., 2005, 706-712, DOI: 10.1039/B417530A; Denti G, Sabatino L, Rosa G D, Bartolotta A, Marco G D, Ricevuto V and Campagna S, Inorg Chem., 1989, 28, 3309-3313, DOI: 10.1021/ic00316a012.

7. Marin V, Hoogenboom, Moore B, Holder E and Schubert U S, Aust J Chem., 2007, 60, 229-235, DOI: 10.1071/CH07015.

8. Ferrari M B, Fava G G, Pelosi G and Denti Gianfranco, J Chem Crystallogr., 1997, 27(4), 257-261, DOI: 10.1007/BF02575965.

9. Hoogenboom R, Kickelbick G and Schubert U S, Eur J Org Chem., 2003, 24, 4887 4896, DOI: 10.1002/ejoc.200300505; Constable E C, Housecroft C E, Kariuki B M, and Smith C B, Aust J Chem., 2003, 56(7), 653-655, DOI: 10.1071/CH03083; Constable E C, Decurtins S, Housecroft C E, Keene T D, Palivan C G, Price J R and Zampese J A, Dalton Trans., 2010, 39, 2337-2343, DOI: 10.1039/b923729a.

10. Butte W A and Case F H, J Org Chem., 1961, 26, 4690-4691.

11. Chakraborty I, Sengupta S, Das S, Banerjee S and Chakravorty A, Dalton Trans., 2003, 134-140, DOI: 10.1039/B208338H.

12. Sawyer D T and Roberts J L, Jr. Experimental Electrochemistry for Chemists, Wiley, New York, 1974, 212.

13. Sengupta S, Gangopadhyay J and Chakravorty A, Dalton Trans., 2003, 4635-4643, DOI: 10.1039/B307834E.

14. Chakraborty I, Bhattacharyya S, Banerjee S, Dirghangi B K and Chakravorty A, $J$ Chem Soc, Dalton Trans., 1999, 3747-3753, DOI: 10.1039/A906460E.

15. Bhattacharyya S, Chakraborty I, Dirghangi B K and Chakravorty A, Chem Commun., 2000, 1813-1814, DOI: 10.1039/B004565I.

16. Cotton F A and Wilkinson, G, Advanced Inorganic Chemistry, 1988, Wiley, New York, $5^{\text {th }}$ Edn., 64. 